\title{
Scientific and legal aspects setting norms in the area of generation and processing of municipal solid waste
}

\author{
Ekaterina Wegner-Kozlova ${ }^{1,2}$ \\ ${ }^{1}$ Institute of Economics The Ural Branch of Russian Academy of Sciences, Moscow str., 29, 620014 \\ Ekaterinburg, Russia \\ ${ }^{2}$ Federal State Autonomous Educational Institution of Higher Education «Ural Federal University \\ named after the first President of Russia B.N. Yeltsin», 620014 Ekaterinburg, Lenin str., 13B, Russia
}

\begin{abstract}
The current situation in Russia concerning generation and disposal of municipal solid waste (MSW) is characterized by significant environmental pollution, irrational use of natural resources and, as a result, significant economic damage. Measures taken at the federal and regional levels is focused on achieving optimal efficiency in waste management. However, an increasing financial burden on legal entities due to higher standards of MSW formation may lead to negative trends in economic development caused by lower competitiveness of enterprises, worsened investment climate and business activity. The study is aimed to assess regulating processes of municipal waste management in connection with the development of an effective system of recycling and reuse of MSW.
\end{abstract}

\section{Introduction}

The current situation in Russia concerning generation and disposal of municipal solid waste (MSW) is characterized by significant environmental pollution, irrational use of natural resources and, as a result, significant economic damage. Undertaken federal and regional measures are focused on achieving economic efficiency in waste management. However, an increasing financial burden on legal entities due to higher standards of MSW formation may lead to negative trends in economic development caused by lower competitiveness of enterprises, worsened investment climate and business activity.

The obvious task of forming an effective system of collection, transportation, recycling, reuse and utilization - which takes into account economic and geographical peculiarities of regions - faces several organizational and institutional constraints in reality.

The practical implementation of this task requires, on the one hand, the implementation of serious research projects, modernization of infrastructure and, consequently, a huge amount of funding. On the other hand, the real sector enterprises are "crushed" by high monopoly prices for resources, energy and transport, which is regularly noted by the Russian business ombudsman. The tariff burden on the real sector is inversely related to its efficiency and competitiveness, which will be even more evident in the "covid-recession". Thus, studies in the field of economic justification, reasonable standards and tariffs, and their impact on the development of competitiveness today are of special importance. 


\section{Materials and Methods}

The studies are carried out by analyzing, conducting critical and statistical evaluation of tariff regulation in the management of municipal solid waste. This paper includes methods of analysis and synthesis, statistical and comparative methods.

The information and analytical basis for the study were obtained from analytical and statistical materials of the Federal State Statistics Service, the Ministry of Natural Resources and Environment of the Russian Federation, the Ministry of Natural Resources and Environment of Sverdlovsk region, the European Statistical Office and the European Environment Agency.

\section{Results and Discussion}

\subsection{EU experience in municipal waste management}

In EU countries, attention to building sustainable ecosystems is characterized by shifting production and consumption processes towards reduction, reuse and recycling. It explains active development of environmental and economic concepts: sustainable development, green economy, blue economy, circular economy, and cradle to cradle concept (see Table $1)$.

Table 1. Concepts of environmental and economic interaction.

\begin{tabular}{|c|c|}
\hline $\begin{array}{c}\text { The } \\
\text { name } \\
\text { of the } \\
\text { conce } \\
\text { pt }\end{array}$ & General description of the concept \\
\hline 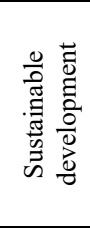 & $\begin{array}{l}\text { Sustainable development means meeting the needs of the } \\
\text { current generation without depriving future generations of } \\
\text { this option. Sustainable development combines the } \\
\text { elaboration and successful implementation of advanced } \\
\text { technologies and their organic integration into the social } \\
\text { and economic sphere together with environmental } \\
\text { protection as an integral part of the development process. }\end{array}$ \\
\hline 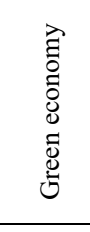 & $\begin{array}{l}\text { The OECD developed and introduced the concept of green } \\
\text { growth, defining it as maximizing economic growth and } \\
\text { progress without affecting the quantity and quality of } \\
\text { natural assets and leveraging the growth potential that } \\
\text { occurs during the shift to the green economy. Green } \\
\text { growth is a GDP increase that focuses on green growth } \\
\text { drivers. }\end{array}$ \\
\hline 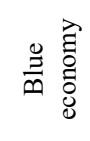 & $\begin{array}{l}\text { In this concept lies the idea that the waste of one product } \\
\text { becomes the raw material that brings new financial flow } \\
\text { [1]. An economy that encourages the switch from a } \\
\text { commodity economy to an economy of systems [2]. }\end{array}$ \\
\hline 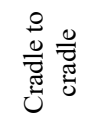 & $\begin{array}{l}\text { The concept of waste-free production based on the } \\
\text { principles of regenerative design [3]. }\end{array}$ \\
\hline 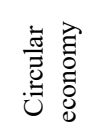 & $\begin{array}{c}\text { The circular economy describes an economic system based } \\
\text { on business models that replace the "end-of-life" concept } \\
\text { with reducing, reusing, recycling material flows in } \\
\text { production, distribution or consumption processes [4]. }\end{array}$ \\
\hline
\end{tabular}


In Europe, the environmental concerns related to potential risk factors and efforts to improve the environment have also become more crucial and popular among government and public organizations. There has emerged a trend of increasing environmentally-oriented and environmentally responsible behavior, which is more focused on targeted reduction of negative impact on the environment [5].

When elaborating international and national waste management plans and strategies, the EU legislation requires to be guided by the "waste hierarchy" presented in the Waste Framework Directive (Figure 1).

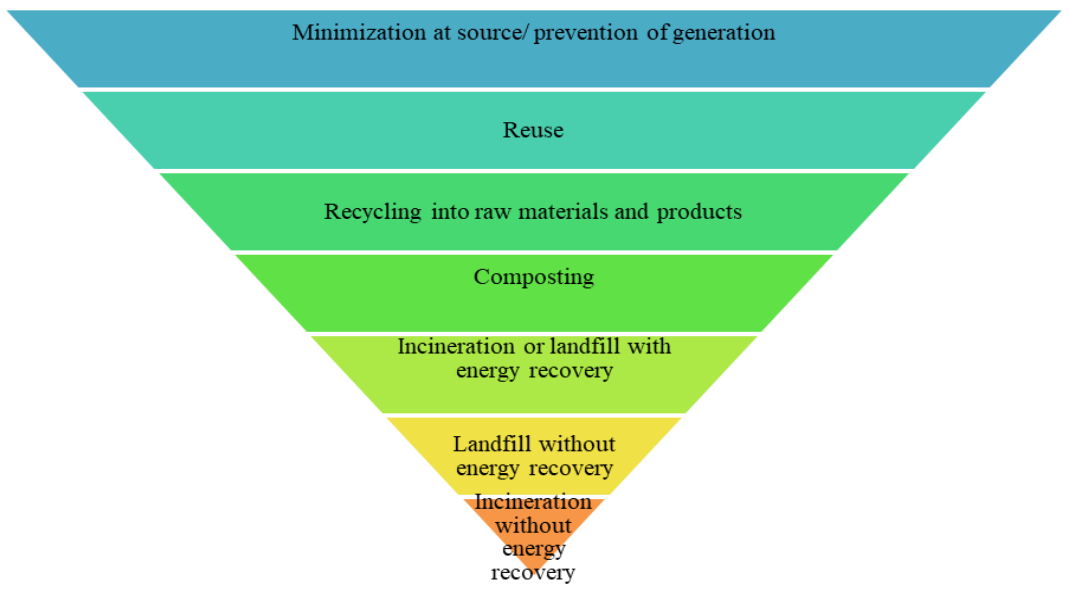

Fig. 1. Waste hierarchy International Waste hierarchy [6].

European countries give preference to waste treatment, which includes: recycling, composting and anaerobic digestion. In 1995-2018, the recycling rate of domestic waste increased by $28.6 \%$, maintaining positive dynamics with an average growth of $104 \%$ (Fig.2).

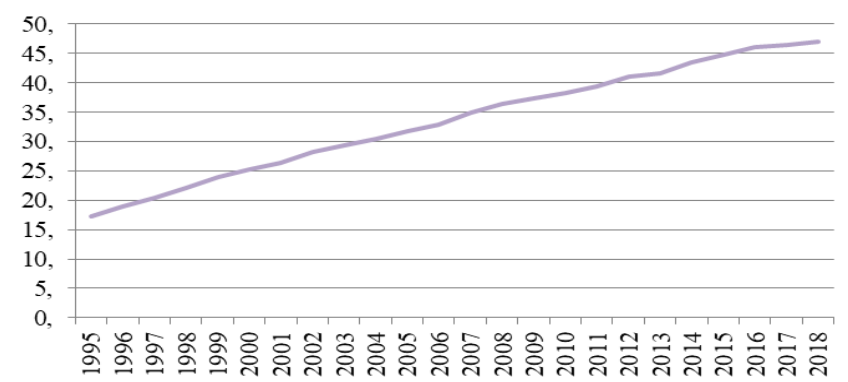

Fig. 2. Recycling rate of municipal waste in the EU, \%

The highest rate of recycled waste belongs to Germany $(67.3 \%)$, Slovenia $(58.9 \%)$, Austria (57.7\%), Netherlands (55.9\%) (Fig. 3). 


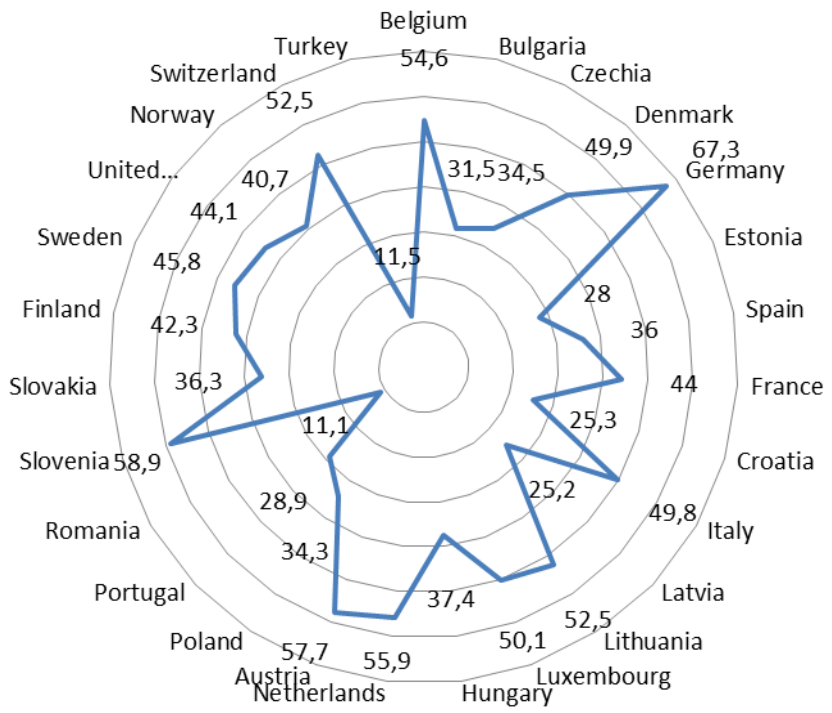

Fig. 3. Recycling rate of municipal waste in $2018, \%$.

Data from the European Environment Agency (Table 2) show that the leading European countries with the lowest rates of solid municipal waste disposal are Switzerland, Netherlands, Germany, Belgium, Sweden, Denmark, Norway and Austria.

Table 2. Solid municipal waste treatment in European countries leading the industry (as percentage of total waste generated) [7].

\begin{tabular}{|c|c|c|c|c|c|}
\hline Country & $\begin{array}{c}\text { Waste } \\
\text { produ } \\
\text { ced } \\
\text { (kg/pe } \\
\text { rson) }\end{array}$ & $\begin{array}{c}\text { Recycli } \\
\mathbf{n g}, \%\end{array}$ & $\begin{array}{c}\text { Compo } \\
\text { sting, } \\
\mathbf{\%}\end{array}$ & $\begin{array}{c}\text { Incineratio } \\
\text { n (thermal } \\
\text { treatment) } \\
\text { of wastes, } \\
\text { \% }\end{array}$ & $\begin{array}{c}\text { Buried, } \\
\%\end{array}$ \\
\hline Germany & 617 & $47 \%$ & $17 \%$ & $35 \%$ & $1 \%$ \\
\hline Switzerland & 702 & $34 \%$ & $17 \%$ & $49 \%$ & $0 \%$ \\
\hline Austria & 578 & $24 \%$ & $35 \%$ & $37 \%$ & $4 \%$ \\
\hline Netherlands & 526 & $24 \%$ & $26 \%$ & $49 \%$ & $1 \%$ \\
\hline Sweden & 458 & $33 \%$ & $16 \%$ & $50 \%$ & $1 \%$ \\
\hline Belgium & 439 & $34 \%$ & $21 \%$ & $44 \%$ & $1 \%$ \\
\hline Denmark & 747 & $28 \%$ & $17 \%$ & $54 \%$ & $1 \%$ \\
\hline Norway & 496 & $24 \%$ & $16 \%$ & $58 \%$ & $2 \%$ \\
\hline
\end{tabular}

It should also be noted that meeting the strict requirements for environmental standards is becoming a competitive factor in global markets.

\subsection{Regulations and legal framework for waste management in Russia}

In recent years, the sphere of solid municipal waste management in Russia has undergone significant upgrading of its regulatory framework. The legal basis of state regulation in the field of MSW management in Russia is formed by legal acts, orders, decrees and methodological guidelines.

The sector strategic planning document that defines the priorities of the government policy in the field of development of the industry for processing of production and consumption waste is the "Industrial Development Strategy for Processing, Utilization and Neutralization of Production and Consumption Waste for the period up to 2030". 
(hereinafter-Strategy). The Strategy is aimed at building up a branch of industry that unites enterprises producing equipment for waste processing, waste processing companies and entities that use waste and products of its treatment as raw materials in technological processes. The Strategy focuses on the creation of an efficient industry for recycling production and consumption waste. The industry is based on industrial production and technical facilities for waste processing, ensuring systematic minimization of the amount of waste not subject to further utilization and neutralization to "zero".

The definition of municipal solid waste is fixed in Federal Law No. 89-Ф3 "On Production and Consumption Waste" signed on June 24, 1998. Municipal solid waste includes household waste generated in the process of consumption by people, as well as goods that have lost their consumer properties during their use by people in the residential premises for personal and domestic needs. Municipal solid waste includes garbage generated during the activity of legal entities, sole proprietors and also waste similar in its composition to garbage generated in residential premises during the consumption by people.

It should be noted that the Federal Law is the most consistent by its content with the principles of "reduction, reuse and recycling". This legal act defines the processes of waste disposal, recycling and recovery. According to this law, waste disposal is the use of waste for the production of goods (products), works, services, including the reuse of waste, and also the reuse of waste for its intended purpose (recycling), its return to the production cycle after appropriate treatment (recovery), the extraction of useful components for its reuse (recuperation), but also the use of solid municipal waste as a renewable energy source (secondary energy resources) after the extraction of useful components from them is done.

The procedure for determining the standards of accumulation of solid municipal waste, which includes procedures for collection, analysis and calculation of amount and volume of accumulated garbage can be found in Rules No. 269 for determining the standards of accumulation of municipal solid waste approved by the Government of the Russian Federation on April 4, 2016.

Russian Government Decree No. 484 "On Pricing in the Field of Municipal Solid Waste Management" dd. May 30, 2016 defines the guidelines, methods for regulating tariffs on goods (works, services) of enterprises engaged in regulated activities in the municipal solid waste management, and also the criteria for their application.

Federal Antimonopoly Service Order No. 1638/16 "On Approval of the Guidelines for Calculating the Regulated Tariffs in the Field of Municipal Solid Waste Management" (as amended) signed on November 21, 2016 contains methodological guidelines for calculating the marginal tariffs in the area of municipal solid waste management. As provided by this Order (para. 7), the tariffs are calculated on the basis of the required gross revenue determined for the appropriate regulated activity and the estimated volume and/or amount of municipal solid waste.

It should be mentioned that the above documents lack tools and real mechanisms to stimulate upgrading of the waste management sphere, increase its efficiency, and develop the separate collection of MSW. The uniform tariff for the regional operator's service of handling MSW is formed on the basis of the regional operator's expenses. The tariff calculation takes into account statutory standards of accumulation of municipal solid waste on the territory of a constituent entity of the Russian Federation. However, the method for determining the standards of accumulation (Methodical Guidelines on Identifying the Standards of Accumulation of Municipal Solid Waste approved by Order No. 524/пр issued by the Russian Ministry of Construction, Housing and Utilities on July 28, 2016) does not suggest determining the morphological composition of the waste (encouraging the development of recycling, recuperation or recovery of waste), and fails to establish methods for measuring the density of waste, which ultimately affects the level of the tariff. 
Therefore, the legal and regulatory framework for managing MSW nowadays, despite the Strategy's goals, does not contribute to development of processing and recycling of waste, leading to "annual lost profits from the processing of at least 68 billion rubles (1.7 billion euros)" [8].

\subsection{Analysing the amount of MSW in Sverdlovsk region}

The amount of municipal waste generated in Sverdlovsk region is constantly growing. Actual MSW volume estimation showed that the total amount of communal waste generated by all categories of facilities (administrative, educational, cultural and entertainment, sports institutions, catering enterprises, service-oriented companies, different industries, apartment buildings and individual houses) increased by $11.7 \%$ during the period under review, which constituted 161.2 thousand tons in absolute terms (Table 3).

Table 3. Volume of municipal waste and solid municipal waste generated by all types of facilities, thousand tons [9].

\begin{tabular}{|c|c|c|c|c|c|}
\hline Indicators & $\mathbf{2 0 1 5}$ & $\mathbf{2 0 1 6}$ & $\mathbf{2 0 1 7}$ & $\mathbf{2 0 1 8}$ & $\begin{array}{c}\text { Absolut } \\
\text { e } \\
\text { growth, } \\
\mathbf{2 0 1 8} / \mathbf{2 0} \\
\mathbf{1 5}\end{array}$ \\
\hline $\begin{array}{c}\text { Volume of municipal waste generated } \\
\text { by all types of facilities, }\end{array}$ & 1765.8 & 1641.5 & 1760.5 & 1974.8 & 209 \\
\hline $\begin{array}{c}\text { Volume of municipal solid waste } \\
\text { (MSW) generated by all types of } \\
\text { facilities }\end{array}$ & 1380.8 & 1285.5 & 1414 & 1542 & 161.2 \\
\hline
\end{tabular}

A human being is the source of MSW generation. It would be reasonable to consider the actually accumulated volume of MSW per person (Table 4).

Table 4. Changes in the actual volume of municipal waste and solid municipal waste per person.

\begin{tabular}{|c|c|c|c|c|c|}
\hline Indicators & $\mathbf{2 0 1 5}$ & $\mathbf{2 0 1 6}$ & $\mathbf{2 0 1 7}$ & $\mathbf{2 0 1 8}$ & $\begin{array}{c}\text { Absolut } \\
\mathbf{e} \\
\text { growth, } \\
\mathbf{2 0 1 8} \\
\mathbf{1 5}\end{array}$ \\
\hline $\begin{array}{c}\text { The population of the Sverdlovsk } \\
\text { region, in total, people }\end{array}$ & $\begin{array}{c}432747 \\
2\end{array}$ & $\begin{array}{c}433000 \\
6\end{array}$ & $\begin{array}{c}432934 \\
1\end{array}$ & $\begin{array}{c}432525 \\
6\end{array}$ & -2216 \\
\hline $\begin{array}{c}\text { Actual volume of municipal waste, } \\
\text { tons per person each year }\end{array}$ & 0.41 & 0.38 & 0.41 & 0.46 & 0.05 \\
\hline $\begin{array}{c}\text { Actual volume of municipal waste, } \\
\text { tons per person each month }\end{array}$ & 0.034 & 0.032 & 0.034 & 0.038 & 0.004 \\
\hline $\begin{array}{c}\text { Actual volume of municipal solid } \\
\text { waste, tons per person each year }\end{array}$ & 0.32 & 0.30 & 0.33 & 0.36 & 0.04 \\
\hline $\begin{array}{c}\text { Actual volume of municipal solid } \\
\text { waste, tons per person each month }\end{array}$ & 0.027 & 0.025 & 0.027 & 0.030 & 0.003 \\
\hline
\end{tabular}

The growth of actual MSW generation during the year was $12.5 \%$.

Standards of municipal waste accumulation for apartment buildings are $0.169 \mathrm{~m} 3$ per month, for individual houses $-0.190 \mathrm{~m} 3$ per month (for the city of Ekaterinburg- 0.213 and $0.261 \mathrm{~m} 3$ respectively) as established by the Decision of the Sverdlovsk Regional Energy Committee on August 30, 2017, No. 77-ПК (ed. June 28, 2018) "On Approval of Standards for Municipal Solid Waste Accumulation in Sverdlovsk Region (except for the city of Ekaterinburg)" and the Decision of the Sverdlovsk Regional Energy Committee 
issued on August 30, 2017, No. 78-ПК (ed. June 28, 2018) "On Approval of Standards for Municipal Solid Waste Accumulation within the Boundaries of the City of Ekaterinburg".

Table 5. Comparative analysis of standard values and actual MSW accumulation volume

\begin{tabular}{|c|c|c|c|c|}
\hline \multirow[t]{3}{*}{ Facility type } & \multicolumn{4}{|c|}{$\begin{array}{c}\text { Standards for MSW accumulation } \\
\text { (Decision No. 93-ПK made by the Sverdlovsk Regional Energy } \\
\text { Committee } \\
\text { on June 28, 2018) }\end{array}$} \\
\hline & \multicolumn{2}{|c|}{ Per month } & \multicolumn{2}{|c|}{ Per year } \\
\hline & kg & $\mathrm{m}^{3}$ & kg & $\mathbf{m}^{3}$ \\
\hline $\begin{array}{l}\text { Apartment } \\
\text { buildings /per } \\
\text { person }\end{array}$ & 33.586 & 0.169 & 403.032 & 2.028 \\
\hline \multirow[t]{2}{*}{$\begin{array}{l}\text { Individual } \\
\text { houses /per } \\
\text { person }\end{array}$} & 30.246 & 0.190 & 362.952 & 2.280 \\
\hline & \multicolumn{4}{|c|}{ The actual volume of MSW } \\
\hline \multirow{3}{*}{$\begin{array}{l}\text { All types of } \\
\text { facilities / per } \\
\text { person }\end{array}$} & \multirow{3}{*}{27.064} & $\begin{array}{c}0.137 \\
(\rho=0,198 \\
g / \mathrm{cm} 3)\end{array}$ & \multirow{3}{*}{324.770} & $\begin{array}{c}1.640 \\
(\rho=0,198 \\
\mathrm{g} / \mathrm{cm} 3)\end{array}$ \\
\hline & & $\begin{array}{c}0.091 \\
(\rho=0,297 \\
g / \mathrm{cm} 3)\end{array}$ & & $\begin{array}{c}1.094 \\
(\rho=0,297 \\
g / \mathrm{cm} 3)\end{array}$ \\
\hline & & $\begin{array}{c}0.034 \\
(\rho=0,800 \\
g / \mathrm{cm} 3)\end{array}$ & & $\begin{array}{c}0.406 \\
(\rho=0,800 \\
g / \mathrm{cm} 3)\end{array}$ \\
\hline
\end{tabular}

Three density values have been taken to calculate the actual MSW volume in m3. This is explained by the fact that the bulk density of MSW in the places of its generation [10] $(\rho=0.198 \mathrm{~g} / \mathrm{cm} 3)$ differs from the density of compacted waste at landfills $[10](\rho=0.800$ $\mathrm{g} / \mathrm{cm} 3$ ). It should be also considered that since the arrival of MSW in garbage trucks, waste also changes its density, which depends on the compaction factor set by the manufacturer for each specific garbage truck model. The Table shows the value $\rho=0.297 \mathrm{~g} / \mathrm{cm} 3$, calculated as a product of the bulk density of MSW in the places of its generation by the compaction factor of 1.5 (however, we should be aware that the compaction factor can vary within 1.5 to 7 depending on the model of garbage trucks [11]).

Given the minimum bulk density of $\operatorname{MSW}(\rho=0.198 \mathrm{~g} / \mathrm{cm} 3)$, the standard which is established for one type of facilities (apartment buildings) exceeds the actual volume of waste generated by all other facilities by $23 \%$.

Growth of financial burden of legal entities due to the excess of MSW generation standards may lead to negative trends for the development of the real sector of the economy associated with decreased competitiveness, worsened investment climate and business activity.

\section{Conclusion}

The performed analysis has revealed, firstly, the fact that goals set in the Strategy, which implementation is possible through development of the waste disposal system (i.e., reuse or recovery of useful properties), are limited by legal acts regulating the sphere of MSW management. And, secondly, the calculation shown by the example of Sverdlovsk region has demonstrated that the established standards for the accumulation of industrial waste, which are the basis for determining the value of the tariff in the field of waste management, do not correspond to the actual volume of waste generated. 
Given the negative social and economic trends (which include negative dynamics of population size, decline in real incomes of people, reduction in the number of small and medium businesses) and in order to clarify the existing MSW standards, it is deemed necessary:

- To establish at the regional level the value of the average density of municipal solid waste so as to compare the volume and mass of municipal solid waste - on the basis of p.4 of Russian Government Decree No. 505 dated June 3, 2016, "On Approval of the Rules of commercial accounting for the volume and (or) mass of municipal solid waste",

- Based on paragraph 2 of Order No. 254/пр issued by the Ministry of Construction, Housing and Utilities on July 28, 2016, to differentiate the standard of MSW depending on the types of waste (related to municipal solid waste), which are defined by the Federal Classification Catalogue of Waste (approved by Order No. 242 of the environmental agency Rosprirodnadzor as of May 22, 2017).

- To analyze the information on the performed measurements of MSW involved in the calculation of the established standard. To carry out comparative monitoring of the volume of actually generated MSW for different types of facilities, using IoT technologies (monitoring sensors for unloading of waste containers, indicators of MSW container content, automated systems for MSW transportation).

- To establish the ratio of standards on the type of residential area, number of residents, and population density.

It is worth mentioning that approaching MSW standards to the real existing volumes of waste contributes to the long-term achievement of targets of the national project "Ecology", as the financial interest of consumers in reducing the volume of MSW will contribute to the reduction of the part of waste directed to recycling and increase the share of waste suitable for treatment.

The study carried out in accordance with the state assignment for the Institute of Economics of the Ural Branch of Russian Academy of Sciences.

\section{References}

1. I.I. Komarova, E.N. Kopteva, A.V. Kondakov, The Latest Productive Forces, 2, 145 (2015)

2. C. Cora, From green to blue economy (2013), https://business.inquirer.net

3. W. McDonough, M. Braungart, Cradle to Cradle: Remaking the Way We Make Things, 202 (2002)

4. J. Kirchherr, D. Reike, M. Hekkert, Resources, Conservation \& Recycling, 127, 221 (2017)

5. A.V. Grebenkin, E.O. Wegner-Kozlova, Proceedings of the First International Scientific and Practical Conference "Digital Transformation of the Industry: Trends, Management, Strategies", 153 (2019)

6. European Waste Management Practice: Issues, Solutions, Perspectives, https://www.waste.ru/

7. Industrial Development Strategy for Processing, Utilization and Neutralization of Production and Consumption Waste by 2030, https://minpromtorg.gov.ru/

8. Waste in Russia: garbage or a precious asset? Scenarios of development of the municipal solid waste management sector, 8 , http://biotech2030.ru/ 
9. Government Report "On the Situation and Protection of the Environment of the Russian Federation in 2018", 157

10. O.M. Guman, O.N. Gryaznov, A.B. Makarov, I.A. Antonova, A.V. Zakharov, Ecological and geological conditions and environmental monitoring of Middle Urals solid domestic waste landfills, 22 (2013)

11. The website Centrkommash LLC, http://www.sweeper.ru/ 